Research Paper

\title{
Increased levels of LAPTM4B, VEGF and survivin are correlated with tumor progression and poor prognosis in breast cancer patients
}

\author{
Sha Li ${ }^{1}$, Lu Wang ${ }^{1}$, Yue Meng ${ }^{1}$, Yanli Chang ${ }^{1}$, Jianjun $X_{u^{1}}$ and Qingyun Zhang ${ }^{1}$ \\ ${ }^{1}$ Department of Clinical Laboratory, Key Laboratory of Carcinogenesis and Translational Research, Ministry of Education, \\ Peking University Cancer Hospital \& Institute, Beijing 100142, China \\ Correspondence to: Qingyun Zhang, email: zhqy_208@163.com \\ Keywords: breast cancer, LAPTM4B, VEGF, survivin, prognosis \\ Abbreviations: LAPTM4B, lysosome-associated protein transmembrane-4 beta; VEGF, vascular endothelial growth factor; OS, \\ overall survival; PFS, progression-free survival \\ Received: December 10,2016 Accepted: March 27, $2017 \quad$ Published: April 18, 2017 \\ Copyright: Li et al. This is an open-access article distributed under the terms of the Creative Commons Attribution License 3.0 (CC \\ BY 3.0), which permits unrestricted use, distribution, and reproduction in any medium, provided the original author and source are \\ credited.
}

\section{ABSTRACT}

Objective: This study explored the relationships among the expression of LAPTM4B, VEGF, and survivin and clinicopathological characteristics and prognosis in breast cancer patients.

Methods: The expression of these three molecules in 110 stage I-III breast cancer patients with clinicopathological and follow-up data was detected via immunohistochemistry. Kaplan-Meier and Cox proportional hazard regression analyses were performed to assess the prognostic significance of these markers in breast cancer. Moreover, expression levels of these markers were evaluated in $\mathbf{5}$ breast cell lines via Western blot analysis.

Results: LAPTM4B, VEGF, and survivin were over-expressed in breast cancer specimens and highly expressed in MDA-MB-231 cells. VEGF and nuclear survivin expression was significantly correlated with LAPTM4B expression, and high levels of all three were associated with a tumor size $\mathbf{2} \mathbf{2 m}$, TNM stage II+III and lymph node metastasis, which had worse impacts on overall survival and progression-free survival in breast cancer patients. A multivariate Cox analysis identified LAPTM4B over-expression as an independent prognostic marker in breast cancer.

Conclusions: These findings suggest that LAPTM4B, VEGF, and nuclear survivin expression are significantly correlated in breast cancer, which may be predictive of prognosis as well as effective therapeutic targets for new anticancer therapies.

\section{INTRODUCTION}

Breast cancer is one of the most common cancers among women, and epidemiological statistics show that the incidence of this disease and its associated mortality are increasing yearly [1]. The identification of key genes that determine progression and metastasis in breast cancer is urgently needed for early diagnoses and molecular targeted therapies.

Lysosome-associated protein transmembrane-4 beta (LAPTM4B), a novel oncogene that belongs to the mammalian 4-tetra-transmembrane spanning protein superfamily, was initially identified in human hepatocellular carcinoma [2, 3]. Previous studies showed that LAPTM4B-35 activity was elevated in various malignant tumors, which was associated with poor prognosis [4-6]. Moreover, it was indicated that LAPTM4B could increase the proliferation and metastasis of tumor cells, reduce apoptosis, and assist drug resistance, which involved in activated PI3K/AKT and Ras-MAPK signaling pathways [7].

Angiogenesis is an important feature of carcinogenesis, progression and metastasis in many human malignancies. Vascular endothelial growth factor (VEGF) is thought to be a major mediator of angiogenesis that promotes the proliferation of tumor cells and boosts 
Table 1: Expression of LAPTM4B, VEGF and survivin in breast tissue specimens

\begin{tabular}{|c|c|c|c|c|c|c|c|c|c|c|}
\hline \multirow[b]{2}{*}{ Groups } & \multirow[b]{2}{*}{$\mathbf{N}$} & \multicolumn{2}{|c|}{ LAPTM4B expression } & \multirow[b]{2}{*}{$\mathbf{P}^{\mathbf{a}}$} & \multicolumn{2}{|c|}{ VEGF expression } & \multirow[b]{2}{*}{$\mathbf{P}^{\mathbf{a}}$} & \multicolumn{2}{|c|}{ Survivin expression } & \multirow[b]{2}{*}{$\mathbf{P}^{\mathbf{a}}$} \\
\hline & & $\begin{array}{c}\text { High } \\
\text { expression }\end{array}$ & $\%$ & & $\begin{array}{c}\text { High } \\
\text { expression }\end{array}$ & $\%$ & & $\begin{array}{c}\text { High } \\
\text { expression }\end{array}$ & $\%$ & \\
\hline $\begin{array}{l}\text { Benign breast } \\
\text { tumor }\end{array}$ & 10 & 1 & 10 & $0.013 *$ & 1 & 10 & $0.007 *$ & 3 & 30 & $0.038 *$ \\
\hline Breast cancer & 110 & 62 & 56.3 & & 66 & 60.0 & & 75 & 68.1 & \\
\hline
\end{tabular}

${ }^{\mathrm{a} C a l c u l a t e d}$ by $\chi 2$ test.

$* \mathrm{P}<0.05$.

invasion and metastasis via the activation of the PI3K/ AKT pathway [8-10]. The vascular density of tumors, including breast cancer, has been proven to be closely correlated with prognosis [11].

Survivin is a $16.5-\mathrm{kDa}$ intracellular protein that is a well-known member of the inhibitor of apoptosis protein family, and its expression is elevated in the majority of tumors [12]. It potentially facilitates cell cycle processes and cell division and reduces apoptotic indices, which is strongly related with poor prognosis in breast cancer $[13,14]$. Transcription from the survivin gene locus gives rise to 5 splice variants [15]. The relation of the splicing variants with prognosis is currently unclear.

Interestingly, a previous study revealed that tissues with elevated expression of LAPTM4B had significantly more new capillary blood vessels than tissues with reduced expression in a mouse xenograft model of liver cancer, indicating that LAPTM4B over-expression might be significantly associated with increased angiogenic activity [16]. Recent studies have also shown that silencing LAPTM4B remarkably reduces the expression of VEGF in HeLa cells [17] and that increased LAPTM4B-35 combined with positive VEGF expression might serve as a new biological marker to predict outcomes in cervical carcinoma [18]. In addition, it has been proven that the upregulation of LAPTM4B-35 promotes the activation of AKT and Bad, which would maintain cell survival [16].

The correlations among LAPTM4B, VEGF, and survivin have not been investigated in breast cancer. Therefore, we performed a retrospective study including 110 breast cancer patients who underwent surgical resection, primarily exploring relationships among the expression of these three markers, clinical variables and survival.

\section{RESULTS}

\section{Expression of LAPTM4B, VEGF, and survivin}

Statistical analyses showed that the expression of these three markers was significantly elevated in breast cancer specimens $(\mathrm{P}<0.05)$ (Table 1). As shown in Figure 1a$1 \mathrm{k}$, LAPTM4B and VEGF protein staining were localized in the cytoplasm. Survivin staining differed among the cases:
63 cases $(57.27 \%)$ showed expression only in the nucleus, $21(19.09 \%)$ only in the cytoplasm, and $17(15.45 \%)$ in both the nucleus and cytoplasm. Additionally, high VEGF and nuclear survivin protein expression were linearly correlated with that of LAPTM4B ( $\mathrm{P}<0.001)$, as shown in Table 2 .

Figure $2 \mathrm{a}$ shows that LAPTM4B, VEGF and survivin expression levels were increased in MDA-MB-231 cells, which were more highly metastatic than the other cell lines. Furthermore, we extracted the nuclear and cytoplasmic fractions in 5 breast cell lines and found that survivin protein expression was highest in the nuclear fractions of highly malignant MDA-MB-231 cells. For the cytoplasmic protein samples, survivin expression in MDA-MB-231 cells was lower than in the other cell lines (Figure 2b).

\section{Relationships between LAPTM4B, VEGF, and survivin protein expression and clinicopathological factors in breast cancer patients}

As shown in Table 3 , high levels of LAPTM4B, VEGF, and nuclear survivin were found in cases where factors related to tumor progression were present, such as tumor sizes $>2 \mathrm{~cm}$, TNM stage II + III and lymph node metastasis. Moreover, there was a significantly positive correlation between LAPTM4B and VEGF expression levels and the probability of tumor-associated venous thrombus $(\mathrm{P}=0.012$ and $\mathrm{P}<0.001$, respectively).

\section{Univariate and multivariate survival analyses}

As shown by the survival analyses, death and recurrence occurred in $12(10.91 \%)$ and 23 cases (20.91\%), respectively. The Kaplan-Meier and log-rank tests showed that tumor sizes $>2 \mathrm{~cm}$ and lymph node metastasis were correlated with poor overall survival (OS) and progressionfree survival (PFS) in breast cancer (Table 4; Figures 3 and 4). A more advanced TNM stage was closely associated with a significantly worse PFS. The univariate model indicated that OS and PFS were significantly lower in cases with elevated LAPTM4B, VEGF, and nuclear survivin levels than in cases with lower levels of these molecules.

The multivariate analysis showed that high levels of LAPTM4B were an independent prognostic marker for 
$\begin{array}{ll}\begin{array}{l}\text { both OS and PFS in breast cancer (Table 5; } \mathrm{P}=0.007 \text { and } \\ \mathrm{P}=0.002, \text { respectively). }\end{array} & \begin{array}{l}\text { breast cancer } \\ \text { importance to } \\ \text { helping to im } \\ \text { A nun }\end{array} \\ \text { DISCUSSION } & \begin{array}{l}\text { proliferation } \\ \text { closely corre }\end{array} \\ \begin{array}{l}\text { Despite the fact that an increasing number of genes } \\ \text { was strongly }\end{array} \\ \begin{array}{l}\text { have been discovered and various targeted therapies have } \\ \text { also been developed in recent years, the survival rate for }\end{array}\end{array}$

$\begin{array}{ll}\begin{array}{l}\text { both OS and PFS in breast cancer (Table 5; } \mathrm{P}=0.007 \text { and } \\ \mathrm{P}=0.002, \text { respectively). }\end{array} & \begin{array}{l}\text { breast cancer } \\ \text { importance to } \\ \text { helping to im } \\ \text { A nun }\end{array} \\ \text { DISCUSSION } & \begin{array}{l}\text { proliferation } \\ \text { closely corre }\end{array} \\ \begin{array}{l}\text { Despite the fact that an increasing number of genes } \\ \text { was strongly }\end{array} \\ \begin{array}{l}\text { have been discovered and various targeted therapies have } \\ \text { also been developed in recent years, the survival rate for }\end{array}\end{array}$

$\begin{array}{ll}\begin{array}{l}\text { both OS and PFS in breast cancer (Table 5; } \mathrm{P}=0.007 \text { and } \\ \mathrm{P}=0.002, \text { respectively). }\end{array} & \begin{array}{l}\text { breast cancer } \\ \text { importance to } \\ \text { helping to im } \\ \text { A nun }\end{array} \\ \text { DISCUSSION } & \begin{array}{l}\text { proliferation } \\ \text { closely corre }\end{array} \\ \begin{array}{l}\text { Despite the fact that an increasing number of genes } \\ \text { was strongly }\end{array} \\ \begin{array}{l}\text { have been discovered and various targeted therapies have } \\ \text { also been developed in recent years, the survival rate for }\end{array}\end{array}$

$\begin{array}{ll}\begin{array}{l}\text { both OS and PFS in breast cancer (Table 5; } \mathrm{P}=0.007 \text { and } \\ \mathrm{P}=0.002, \text { respectively). }\end{array} & \begin{array}{l}\text { breast cancer } \\ \text { importance to } \\ \text { helping to im } \\ \text { A nun }\end{array} \\ \text { DISCUSSION } & \begin{array}{l}\text { proliferation } \\ \text { closely corre }\end{array} \\ \begin{array}{l}\text { Despite the fact that an increasing number of genes } \\ \text { was strongly }\end{array} \\ \begin{array}{l}\text { have been discovered and various targeted therapies have } \\ \text { also been developed in recent years, the survival rate for }\end{array}\end{array}$

$\begin{array}{ll}\begin{array}{l}\text { both OS and PFS in breast cancer (Table 5; } \mathrm{P}=0.007 \text { and } \\ \mathrm{P}=0.002, \text { respectively). }\end{array} & \begin{array}{l}\text { breast cancer } \\ \text { importance to } \\ \text { helping to im } \\ \text { A nun }\end{array} \\ \text { DISCUSSION } & \begin{array}{l}\text { proliferation } \\ \text { closely corre }\end{array} \\ \begin{array}{l}\text { Despite the fact that an increasing number of genes } \\ \text { was strongly }\end{array} \\ \begin{array}{l}\text { have been discovered and various targeted therapies have } \\ \text { also been developed in recent years, the survival rate for }\end{array}\end{array}$

$\begin{array}{ll}\begin{array}{l}\text { both OS and PFS in breast cancer (Table 5; } \mathrm{P}=0.007 \text { and } \\ \mathrm{P}=0.002, \text { respectively). }\end{array} & \begin{array}{l}\text { breast cancer } \\ \text { importance to } \\ \text { helping to im } \\ \text { A nun }\end{array} \\ \text { DISCUSSION } & \begin{array}{l}\text { proliferation } \\ \text { closely corre }\end{array} \\ \begin{array}{l}\text { Despite the fact that an increasing number of genes } \\ \text { was strongly }\end{array} \\ \begin{array}{l}\text { have been discovered and various targeted therapies have } \\ \text { also been developed in recent years, the survival rate for }\end{array}\end{array}$

breast cancer is not satisfactory [19]. Thus, it is of great importance to identify biomarkers that are effective in helping to improve the prognosis in breast cancer.

A number of studies have shown that the proliferation of cells overexpressing LAPTM4B is closely correlated with tumor progression and metastasis [20, 21]. In our study, increased LAPTM4B expression was strongly associated with prognosis-related features,
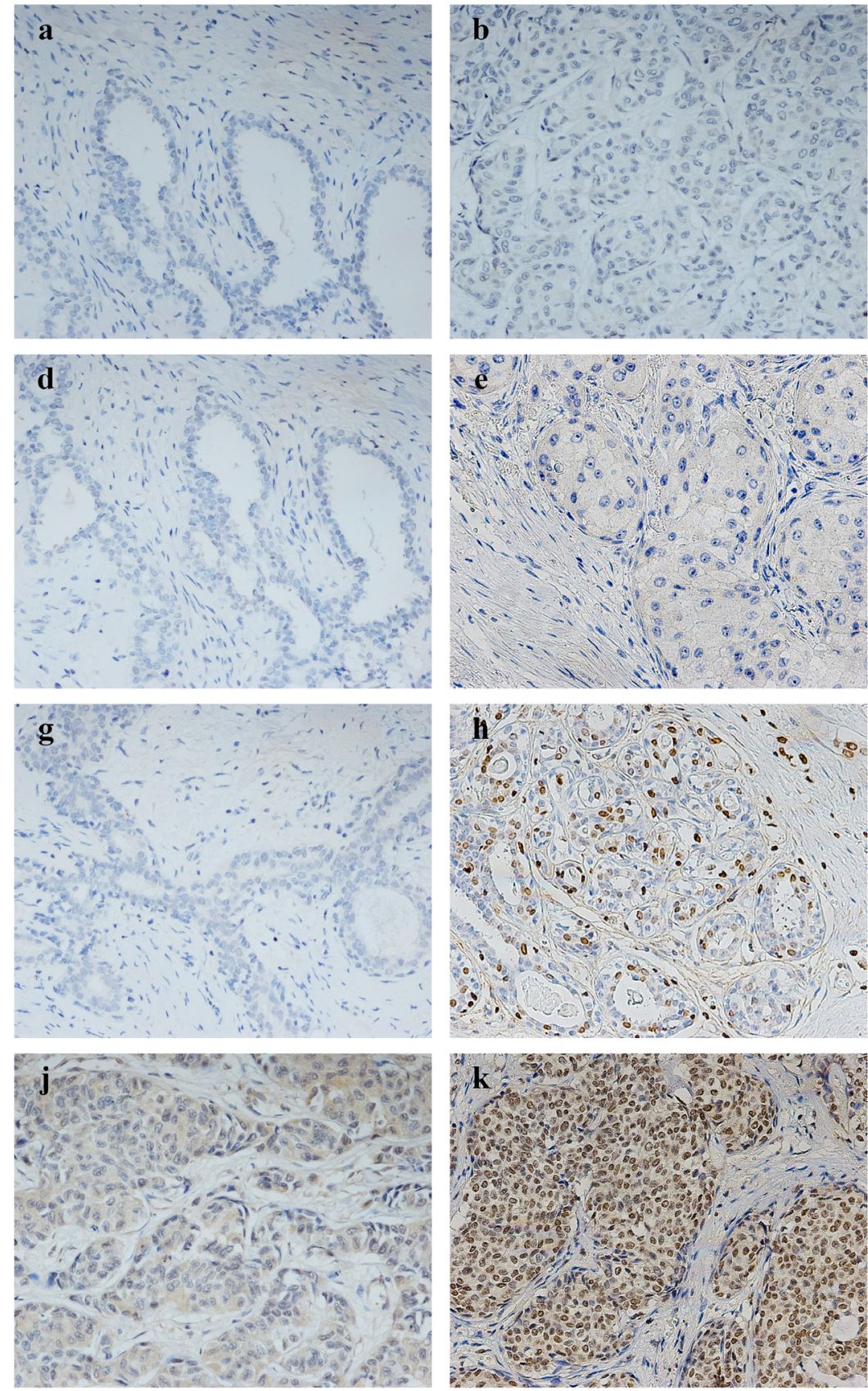
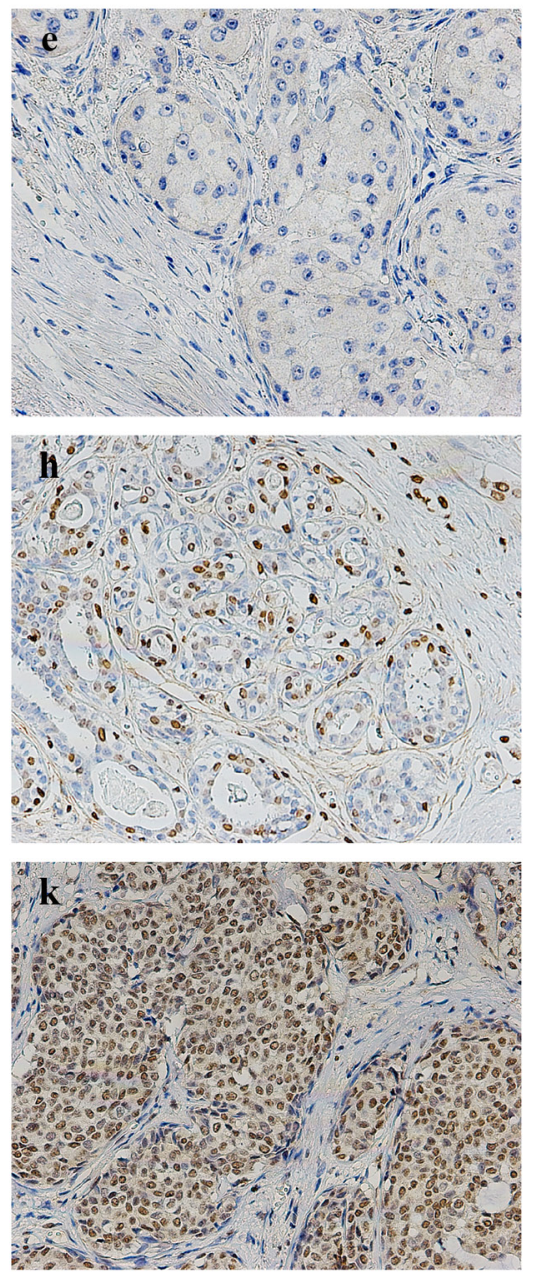
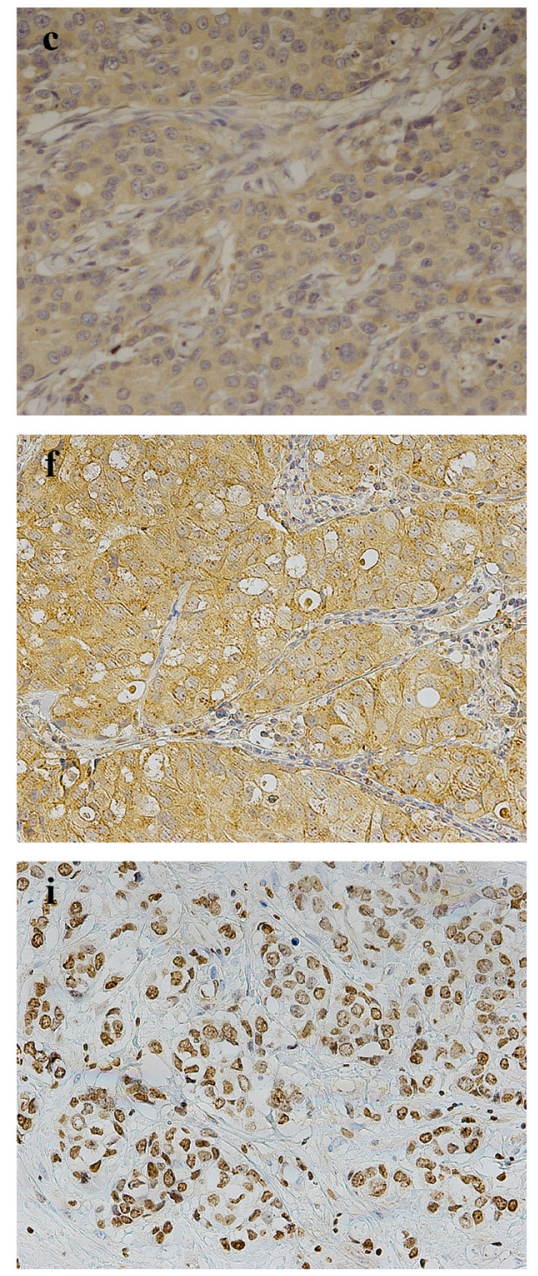

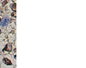


Table 2: Correlations among LAPTM4B, VEGF and survivin in 110 breast cancer patients

\begin{tabular}{lccc}
\hline & Total no. & \multicolumn{2}{c}{ LAPTM4B } \\
\cline { 3 - 4 } & & Low expression & High expression \\
\hline VEGF & 110 & 48 & 62 \\
Total no. & 44 & 14 & 52 \\
Low expression & 66 & 34 & 10 \\
High expression & & & \\
Nuclear survivin & 89 & 35 & 54 \\
Total no. & 27 & 12 & 50 \\
Low expression & 62 & 23 & 4 \\
High expression & & & \\
Cytoplasmic survivin & 47 & 33 & 14 \\
Total no. & 22 & 15 & 10 \\
Low expression & 25 & 18 & 4 \\
High expression & & & 0.103 \\
\hline
\end{tabular}

${ }^{\mathrm{a} C a l c u l a t e d}$ by $\chi^{2}$ test.

$* \mathrm{P}<0.001$.

including tumor size, TNM stage and lymph node metastasis. Further analysis revealed that breast cancer patients with high levels of LAPTM4B protein expression had worse OS and PFS rates.

Our study found that the relationship between VEGF and nuclear survivin expression levels and the expression of LAPTM4B was remarkable. Furthermore, several reports have shown that VEGF could stimulate survivin expression via the PI3K/AKT pathway [22]. This up-regulation of survivin was found to enhance tumor angiogenesis mediated by VEGF $[15,23]$, suggesting the need for further research into the clinical relevance of these three molecules.

In a further step, strategies should be developed to determine whether the detection of LAPTM4B in combination with other molecules is of diagnostic and prognostic value in assessing breast carcinoma cases. Tang et al. examined LAPTM4B and CD34 proteins in non-small cell lung cancer, and their results revealed that LAPTM4B might promote tumor progression by inducing tumor angiogenesis [24]. Meng et al. indicated that the downregulation of LAPTM4B suppressed tumor

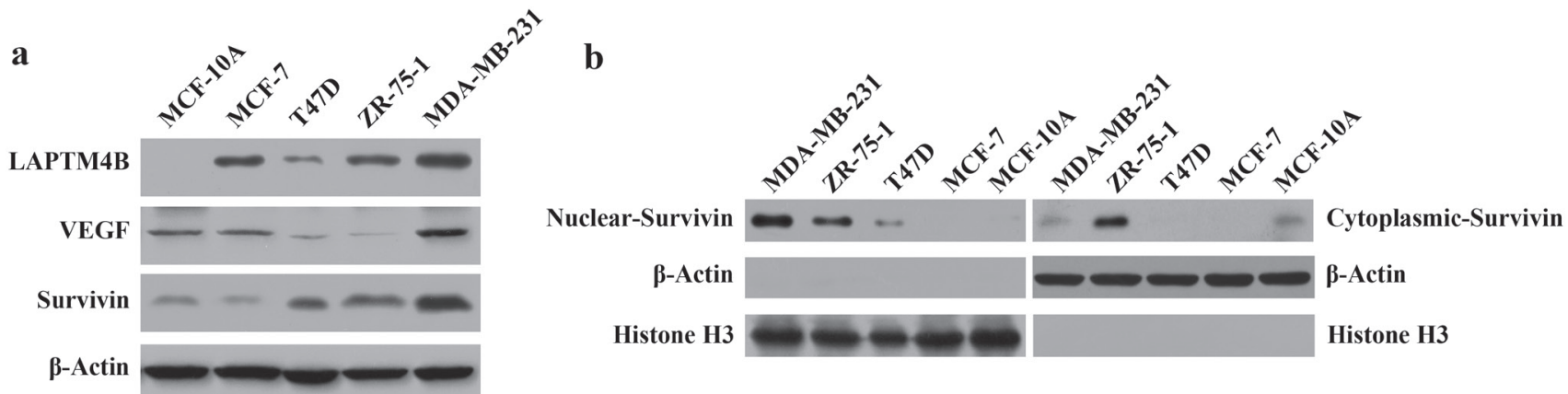

Figure 2: LAPTM4B, VEGF, nuclear and cytoplasmic survivin protein expression in breast cell lines by Western blot analysis. Protein samples were obtained from 5 breast cell lines (MDA-MB-231, ZR-75-1, T47D, MCF-7 and MCF-10A). (a) $\beta$-Actin was used as an internal control for the total protein. High expression of LAPTM4B, VEGF and survivin was detected in MDA-MB-231 cells. (b) Histone $\mathrm{H} 3$ and $\beta$-Actin were used as an internal control for the nuclear and cytoplasmic protein samples, respectively. High levels of survivin were expressed in the nuclear protein of MDA-MB-231 cells. 
Table 3: Associations between the expression levels of LAPTM4B, VEGF and survivin and clinicopathological factors in 110 breast cancer patients

\begin{tabular}{|c|c|c|c|c|c|c|c|c|}
\hline \multirow[t]{2}{*}{ Characteristics } & $\begin{array}{l}\text { LAPTM4B } \\
\text { expression }\end{array}$ & \multirow[t]{2}{*}{$\mathbf{P}^{\mathbf{a}}$} & \multirow{2}{*}{$\begin{array}{c}\text { VEGF } \\
\text { expression } \\
\text { High /Low }\end{array}$} & \multirow[t]{2}{*}{$\mathbf{P}^{\mathbf{a}}$} & \multirow{2}{*}{$\begin{array}{c}\text { Nuclear } \\
\text { survivin } \\
\text { expression } \\
\text { High /Low }\end{array}$} & \multirow[t]{2}{*}{$\mathbf{P}^{\mathbf{a}}$} & \multirow{2}{*}{$\begin{array}{c}\text { Cytoplasmic } \\
\text { survivin expression } \\
\text { High /Low }\end{array}$} & \multirow[t]{2}{*}{$\mathbf{P}^{\mathbf{a}}$} \\
\hline & High /Low & & & & & & & \\
\hline Patient No. & $62 / 48$ & & $66 / 44$ & & $62 / 27$ & & $25 / 22$ & \\
\hline Age (years) & & 0.290 & & 0.936 & & 0.424 & & 0.344 \\
\hline$\leq 55$ & $21 / 21$ & & $25 / 17$ & & $22 / 12$ & & $8 / 10$ & \\
\hline$>55$ & $41 / 27$ & & $41 / 27$ & & $40 / 15$ & & $17 / 12$ & \\
\hline $\begin{array}{l}\text { Menopausal } \\
\text { status }\end{array}$ & & 0.178 & & 0.507 & & 0.279 & & 0.351 \\
\hline Pre-menopausal & $17 / 19$ & & $20 / 16$ & & $18 / 11$ & & $7 / 9$ & \\
\hline Post-menopausal & $45 / 29$ & & $46 / 28$ & & $44 / 16$ & & $18 / 13$ & \\
\hline Tumor size $(\mathrm{cm})$ & & $<0.001 *$ & & $<0.001 *$ & & $0.001 *$ & & 0.355 \\
\hline$\leq 2$ & $8 / 24$ & & $11 / 21$ & & $13 / 15$ & & $6 / 8$ & \\
\hline$>2$ & $54 / 24$ & & $55 / 23$ & & $49 / 12$ & & $19 / 14$ & \\
\hline $\begin{array}{l}\text { Histological } \\
\text { type }\end{array}$ & & 0.607 & & 0.350 & & 0.873 & & 0.280 \\
\hline IDC & $55 / 41$ & & $56 / 40$ & & $52 / 23$ & & $22 / 22$ & \\
\hline Others & $7 / 7$ & & $10 / 4$ & & $10 / 4$ & & $3 / 0$ & \\
\hline $\begin{array}{l}\text { Histological } \\
\text { grade }\end{array}$ & & 0.053 & & 0.089 & & 0.230 & & 0.697 \\
\hline G1 & $5 / 10$ & & $6 / 9$ & & $8 / 7$ & & $2 / 2$ & \\
\hline G2/G3 & $57 / 38$ & & $60 / 35$ & & $54 / 20$ & & $23 / 20$ & \\
\hline TNM stage & & $<0.001^{*}$ & & $<0.001 *$ & & $0.001 *$ & & 0.355 \\
\hline I & $6 / 23$ & & $9 / 20$ & & $11 / 14$ & & $6 / 8$ & \\
\hline II /III & $56 / 25$ & & $57 / 24$ & & $51 / 13$ & & $19 / 14$ & \\
\hline $\begin{array}{l}\text { Lymph node } \\
\text { metastasis }\end{array}$ & & $<0.001^{*}$ & & $<0.001^{*}$ & & $<0.001^{*}$ & & 0.072 \\
\hline No & $16 / 33$ & & $20 / 29$ & & $19 / 19$ & & $13 / 17$ & \\
\hline Yes & $46 / 15$ & & $46 / 15$ & & $43 / 8$ & & $12 / 5$ & \\
\hline $\begin{array}{l}\text { Tumor thrombus } \\
\text { in vena }\end{array}$ & & $0.012 *$ & & $<0.001 *$ & & 0.607 & & 0.058 \\
\hline No & $38 / 40$ & & $38 / 40$ & & $45 / 21$ & & $14 / 18$ & \\
\hline Yes & $24 / 8$ & & $28 / 4$ & & $17 / 6$ & & $11 / 4$ & \\
\hline ER status & & 0.121 & & 0.234 & & 0.077 & & 0.137 \\
\hline Negative & $15 / 6$ & & $15 / 6$ & & $12 / 2$ & & $8 / 3$ & \\
\hline Positive & $47 / 42$ & & $51 / 38$ & & $50 / 25$ & & $17 / 19$ & \\
\hline $\begin{array}{l}\text { PR status } \\
\text { Negative }\end{array}$ & $20 / 14$ & 0.727 & $22 / 12$ & 0.656 & $18 / 8$ & 0.954 & $10 / 8$ & 0.798 \\
\hline Positive & $42 / 34$ & & $44 / 32$ & & $44 / 19$ & & $15 / 14$ & \\
\hline
\end{tabular}




\begin{tabular}{|c|c|c|c|c|c|c|c|c|}
\hline \multirow[t]{2}{*}{ Characteristics } & $\begin{array}{l}\text { LAPTM4B } \\
\text { expression }\end{array}$ & $\mathbf{P}^{\mathbf{a}}$ & $\begin{array}{c}\text { VEGF } \\
\text { expression }\end{array}$ & $\mathbf{P}^{\mathbf{a}}$ & $\begin{array}{c}\text { Nuclear } \\
\text { survivin } \\
\text { expression }\end{array}$ & $\mathbf{P}^{\mathbf{a}}$ & $\begin{array}{c}\text { Cytoplasmic } \\
\text { survivin expression }\end{array}$ & $\mathbf{P}^{\mathbf{a}}$ \\
\hline & High /Low & & High /Low & & High /Low & & High /Low & \\
\hline Her-2 status & & 0.130 & & 0.119 & & 0.478 & & 0.556 \\
\hline Negative & $44 / 40$ & & $47 / 37$ & & $48 / 19$ & & $20 / 16$ & \\
\hline Positive & $18 / 8$ & & $19 / 7$ & & $14 / 8$ & & $5 / 6$ & \\
\hline Recurrence & & 0.336 & & $0.044 *$ & & 0.090 & & 0.855 \\
\hline No & $47 / 40$ & & $48 / 39$ & & $45 / 24$ & & $21 / 19$ & \\
\hline Yes & $15 / 8$ & & $18 / 5$ & & $17 / 3$ & & $4 / 3$ & \\
\hline
\end{tabular}

${ }^{\mathrm{a}}$ Calculated by $\chi^{2}$ test.

$* \mathrm{P}<0.05$.

Table 4: Univariate Kaplan-Meier survival analysis of OS and PFS in 110 breast cancer patients

\begin{tabular}{|c|c|c|c|c|c|c|c|}
\hline \multirow{2}{*}{ Variables } & \multirow{2}{*}{$\mathbf{N}$} & \multicolumn{2}{|c|}{ OS (months) } & \multirow{2}{*}{$\mathbf{P}^{\mathbf{a}}$} & \multicolumn{2}{|c|}{ PFS (months) } & \multirow{2}{*}{$\mathbf{P}^{\mathbf{a}}$} \\
\hline & & Mean \pm SE & $95 \%$ CI & & Mean \pm SE & $95 \%$ CI & \\
\hline Age (years) & & & & 0.437 & & & 0.366 \\
\hline$\leq 55$ & 42 & $50.000 \pm 1.561$ & $46.941-53.059$ & & $48.000 \pm 3.121$ & $41.882-54.118$ & \\
\hline$>55$ & 68 & $46.000 \pm 2.257$ & $41.577-50.423$ & & $44.000 \pm 1.805$ & $40.463-47.537$ & \\
\hline $\begin{array}{l}\text { Menopausal } \\
\text { status }\end{array}$ & & & & 0.186 & & & 0.183 \\
\hline Pre-menopausal & 36 & $51.000 \pm 1.420$ & $48.218-53.782$ & & $50.000 \pm 2.860$ & $44.394-55.606$ & \\
\hline $\begin{array}{l}\text { Post- } \\
\text { menopausal }\end{array}$ & 74 & $46.000 \pm 2.121$ & $41.842-50.158$ & & $44.000 \pm 1.885$ & $40.306-47.694$ & \\
\hline $\begin{array}{l}\text { Tumor size } \\
(\mathrm{cm})\end{array}$ & & & & $0.027 *$ & & & $0.009 *$ \\
\hline$\leq 2$ & 32 & $52.000 \pm 1.697$ & $48.674-55.326$ & & $52.000 \pm 1.697$ & $48.674-55.326$ & \\
\hline$>2$ & 78 & $45.000 \pm 1.778$ & $41.514-48.486$ & & $43.000 \pm 1.068$ & $40.907-45.093$ & \\
\hline $\begin{array}{l}\text { Histological } \\
\text { type }\end{array}$ & & & & 0.613 & & & 0.665 \\
\hline IDC & 96 & $48.000 \pm 1.854$ & $44.367-51.633$ & & $46.000 \pm 1.722$ & $42.625-49.375$ & \\
\hline Others & 14 & $51.000 \pm 4.330$ & $42.513-59.487$ & & $47.000 \pm 6.062$ & $35.118-58.882$ & \\
\hline $\begin{array}{l}\text { Histological } \\
\text { grade }\end{array}$ & & & & 0.390 & & & 0.333 \\
\hline G1 & 15 & $52.000 \pm 3.146$ & $45.835-58.165$ & & $52.000 \pm 1.797$ & $48.477-55.523$ & \\
\hline $\mathrm{G} 2 / \mathrm{G} 3$ & 95 & $48.000 \pm 1.914$ & $44.248-51.752$ & & $44.000 \pm 1.499$ & $41.063-46.937$ & \\
\hline TNM stage & & & & 0.077 & & & $0.033 *$ \\
\hline I & 29 & $52.000 \pm 2.596$ & $46.911-57.089$ & & $52.000 \pm 2.596$ & $46.911-57.089$ & \\
\hline II /III & 81 & $47.000 \pm 2.205$ & $42.678-51.322$ & & $44.000 \pm 0.976$ & $42.087-45.913$ & \\
\hline
\end{tabular}

(Continued) 


\begin{tabular}{|c|c|c|c|c|c|c|c|}
\hline \multirow{2}{*}{ Variables } & \multirow{2}{*}{$\mathbf{N}$} & \multicolumn{2}{|c|}{ OS (months) } & \multirow{2}{*}{$\mathbf{P}^{\mathbf{a}}$} & \multicolumn{2}{|c|}{ PFS (months) } & \multirow{2}{*}{$\mathbf{P}^{\mathbf{a}}$} \\
\hline & & Mean $\pm \mathbf{S E}$ & $95 \%$ CI & & Mean $\pm \mathbf{S E}$ & $95 \%$ CI & \\
\hline $\begin{array}{l}\text { Lymph node } \\
\text { metastasis }\end{array}$ & & & & $0.021 *$ & & & $0.010^{*}$ \\
\hline No & 49 & $51.000 \pm 1.916$ & $47.244-54.756$ & & $51.000 \pm 2.000$ & $47.080-54.920$ & \\
\hline Yes & 61 & $45.000 \pm 1.760$ & $41.550-48.450$ & & $44.000 \pm 1.439$ & $41.179-46.821$ & \\
\hline $\begin{array}{l}\text { Tumor } \\
\text { thrombus in } \\
\text { vena }\end{array}$ & & & & 0.366 & & & 0.315 \\
\hline No & 78 & $49.000 \pm 1.612$ & $45.840-52.160$ & & $48.000 \pm 1.881$ & $44.313-51.687$ & \\
\hline Yes & 32 & $47.000 \pm 3.339$ & $40.456-53.544$ & & $44.000 \pm 2.782$ & $38.546-49.454$ & \\
\hline ER status & & & & 0.201 & & & 0.190 \\
\hline Negative & 21 & $45.000 \pm 1.831$ & $41.411-48.589$ & & $43.000 \pm 1.144$ & $40.757-45.243$ & \\
\hline Positive & 89 & $50.000 \pm 1.347$ & $47.360-52.640$ & & $48.000 \pm 1.886$ & $44.304-51.696$ & \\
\hline PR status & & & & 0.841 & & & 0.931 \\
\hline Negative & 34 & $47.000 \pm 2.328$ & $42.436-51.564$ & & $43.000 \pm 1.458$ & $40.143-45.857$ & \\
\hline Positive & 76 & $50.000 \pm 1.337$ & $47.379-52.621$ & & $48.000 \pm 1.743$ & $44.584-51.416$ & \\
\hline Her-2 status & & & & 0.982 & & & 0.669 \\
\hline Negative & 84 & $49.000 \pm 1.309$ & $46.434-51.566$ & & $48.000 \pm 1.666$ & $44.735-51.265$ & \\
\hline Positive & 26 & $45.000 \pm 2.550$ & $40.003-49.997$ & & $44.000 \pm 3.389$ & $37.357-50.643$ & \\
\hline LAPTM4B & & & & $0.004 *$ & & & $0.001 *$ \\
\hline Low & 48 & $51.000 \pm 1.954$ & $41.170-54.830$ & & $50.000 \pm 1.873$ & $46.329-53.671$ & \\
\hline High & 62 & $45.000 \pm 1.687$ & $41.693-48.307$ & & $44.000 \pm 0.781$ & $42.470-45.530$ & \\
\hline VEGF & & & & $0.010^{*}$ & & & $0.003 *$ \\
\hline Low & 44 & $51.000 \pm 1.873$ & $47.329-54.671$ & & $51.000 \pm 1.561$ & 47.941-54.059 & \\
\hline High & 66 & $45.000 \pm 1.195$ & $42.658-47.342$ & & $44.000 \pm 0.446$ & $43.126-44.874$ & \\
\hline $\begin{array}{l}\text { Nuclear } \\
\text { survivin }\end{array}$ & & & & $0.022 *$ & & & $0.009 *$ \\
\hline Low & 27 & $48.000 \pm 3.674$ & $40.799-55.201$ & & $48.000 \pm 3.674$ & $40.799-55.201$ & \\
\hline High & 62 & $47.000 \pm 2.789$ & $41.534-52.466$ & & $44.000 \pm 0.970$ & $42.099-45.901$ & \\
\hline $\begin{array}{l}\text { Cytoplasmic } \\
\text { survivin }\end{array}$ & & & & 0.875 & & & 0.868 \\
\hline Low & 22 & $48.000 \pm 2.152$ & $43.782-52.218$ & & $48.000 \pm 2.152$ & $43.782-52.218$ & \\
\hline High & 25 & $53.000 \pm 1.208$ & $50.633-55.367$ & & $53.000 \pm 3.019$ & $47.083-58.917$ & \\
\hline
\end{tabular}

OS, overall survival; PFS, progression-free survival; CI, confidence interval.

${ }^{\mathrm{a}}$ Log-rank test.

$* \mathrm{P}<0.05$.

migration and invasion and significantly decreased VEGF expression. Subsequently, they verified that the coexpression of LAPTM4B and VEGF resulted in poor prognosis for cervical cancer $[17,18]$. Consistent with these findings, our results show that high levels of
LAPTM4B and VEGF led to poor clinical outcomes with regard to OS and PFS.

$\mathrm{Li}$ et al. revealed that nuclear survivin levels might predict poor survival in breast cancer [25]. The present study indicates that survivin expression is predominantly 
nuclear rather than cytoplasmic [26], which is line with the majority of previous results. Interestingly, a few reports have indicated that the expression of survivin is nearly equivalent in the nucleus and cytoplasm [27] or only occurs in the cytoplasm [28], which might be attributed to differences in reagents, tissues and clinical stages. In our studies, we separately analyzed the expression of nuclear and cytoplasmic survivin. According to the statistical analyses, nuclear survivin

$\mathbf{a}$

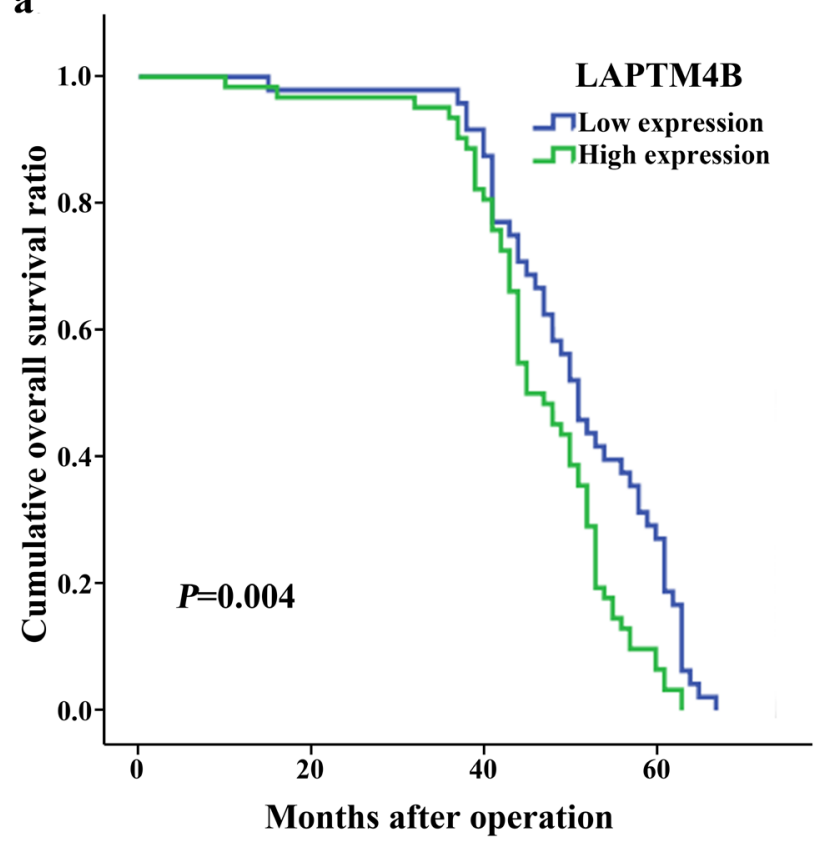

c

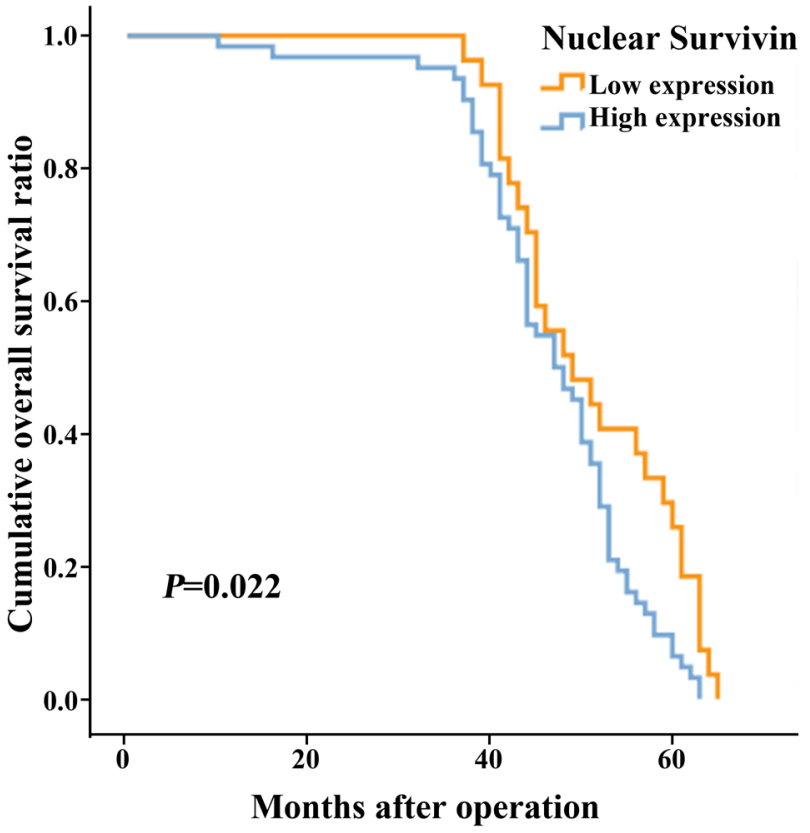

protein expression was dramatically associated with tumor progression and poor survival. Researchers have found LAPTM4B-35 accelerates tumorigenesis in transgenic mice by upregulating the antiapoptotic molecule Bcl2 and downregulating the proapoptotic molecule Bax. However, the expression of survivin in Ad-AE-infected cells was not altered [16]. Hence, the relationship of the subcellular localization of survivin with other molecules should be further investigated as a greater understanding

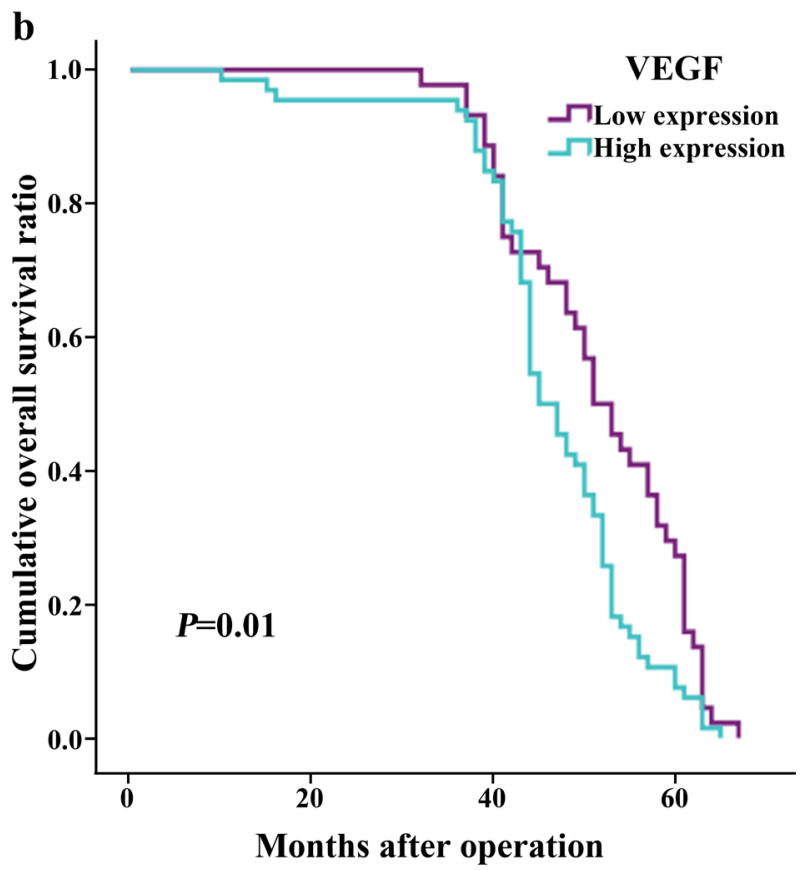

d

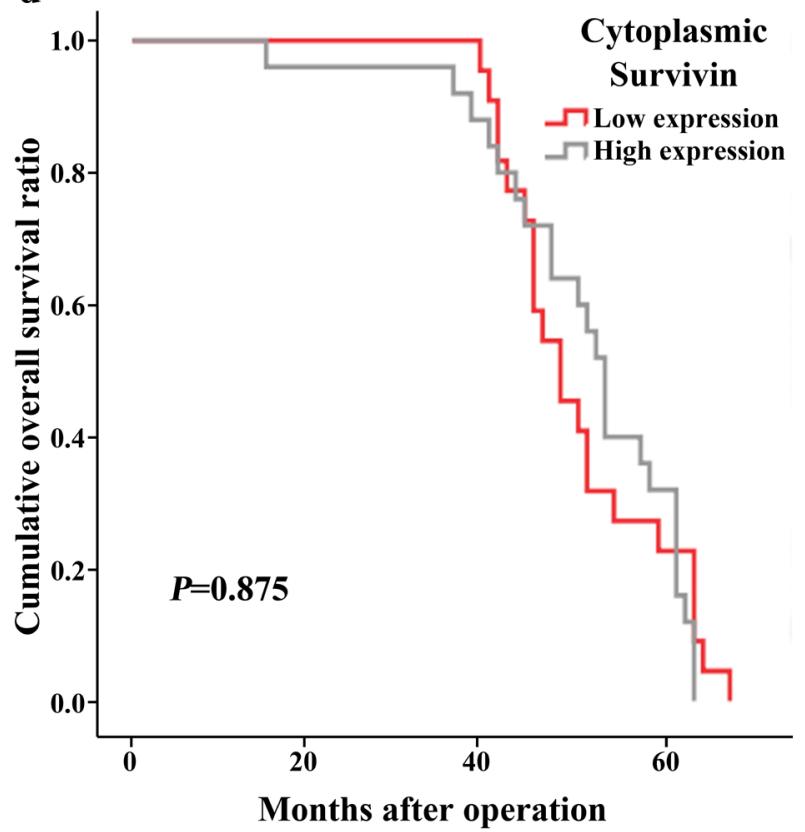

Figure 3: Kaplan-Meier curves for overall survival in 110 patients with breast cancer. High expression of LAPTM4B (a), VEGF (b) and nuclear survivin (c) was significantly associated with poor overall survival $(\mathrm{P}=0.004,0.01$ and 0.022$)$. 
of this relationship could improve prognostic assessments and individualized therapies.

Fan et al. suggested that LAPTM4B*2 was associated with an increased risk of breast cancer in a cohort of Chinese women [29]. Li et al. demonstrated that MDA-MB-231 cells that had the *2/2 genotype exhibited increased LAPTM4B expression [30]. Similar to these results, our study demonstrated that increased VEGF and nuclear survivin expression occurs in MDA-MB-231 cells.

In conclusion, our findings indicate for the first time that LAPTM4B, VEGF, and survivin protein expression is significantly associated with various clinicopathological characteristics and prognosis in breast cancer patients. In particular, the relation of VEGF and survivin protein levels with the expression of LAPTM4B indicates that
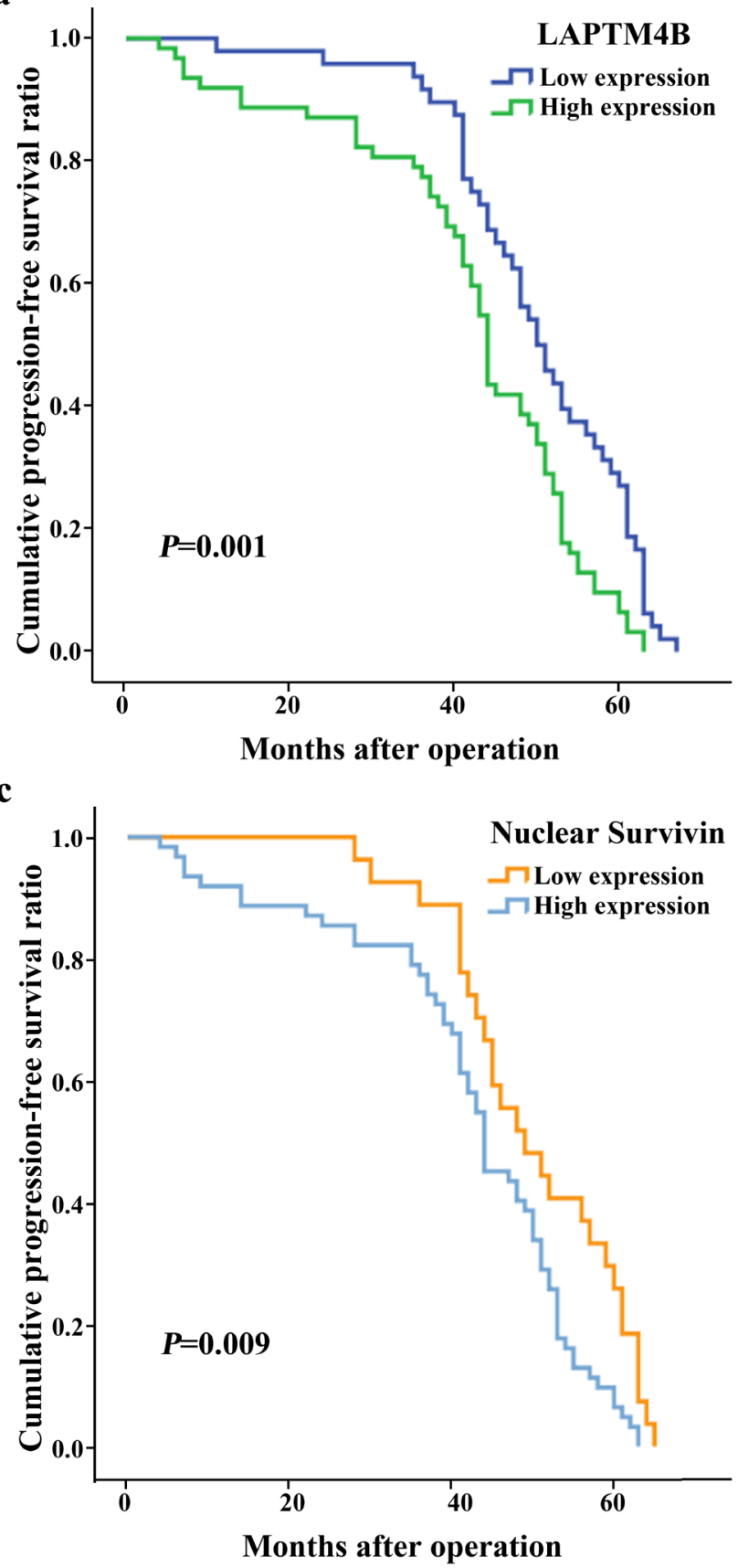

b

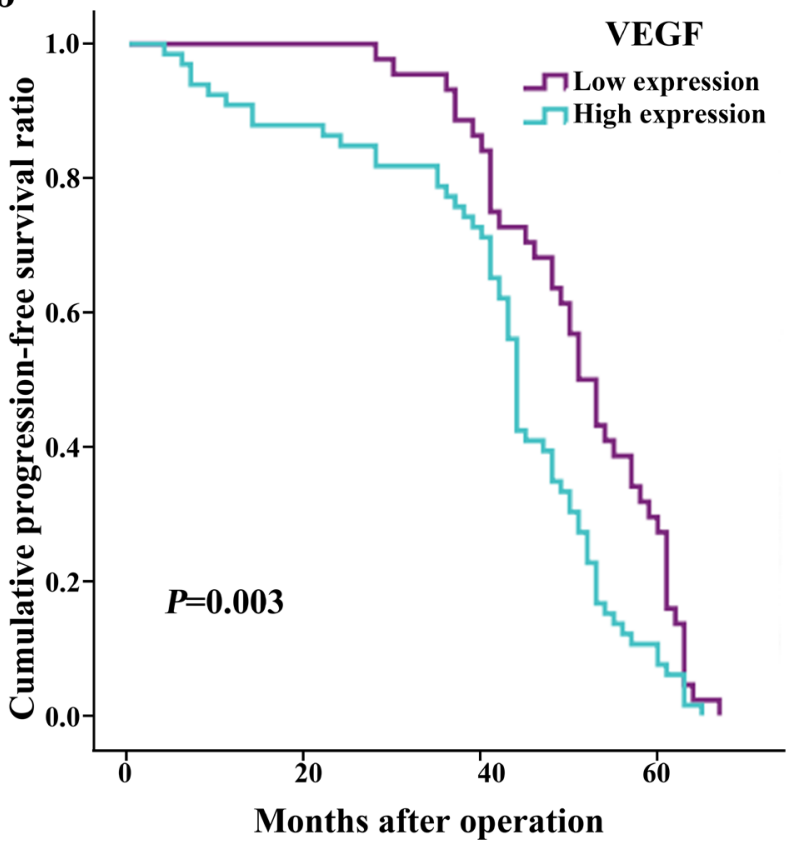

d

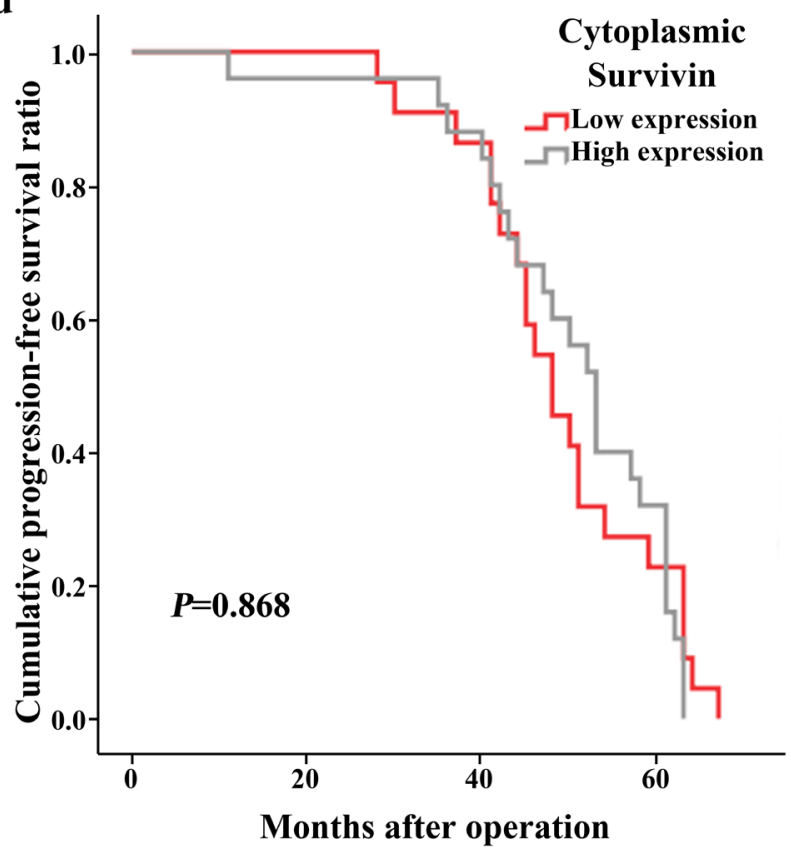

Figure 4: Kaplan-Meier curves for progression-free survival in 110 patients with breast cancer. The progression-free survival was statistically shorter in groups with elevated expression of LAPTM4B (a), VEGF (b) and nuclear survivin (c) $(\mathrm{P}=0.001,0.003$ and 0.009). Expression of cytoplasmic survivin (d) was not related to the progression-free survival. 
Table 5: Multivariate Cox regression analysis of various predictive factors for OS and PFS in 110 breast cancer patients

\begin{tabular}{|c|c|c|c|c|c|c|}
\hline \multirow{2}{*}{ Variables } & \multicolumn{3}{|c|}{ OS (months) } & \multicolumn{3}{|c|}{ PFS (months) } \\
\hline & $\mathbf{R} \mathbf{R}$ & $95 \% \mathrm{CI}$ & $\mathbf{P}^{\mathbf{a}}$ & $\mathbf{R R}$ & $95 \%$ CI & $\mathbf{P}^{\mathbf{a}}$ \\
\hline Tumor size $(\mathrm{cm})$ & N/A & $\mathrm{N} / \mathrm{A}$ & N/A & N/A & N/A & N/A \\
\hline TNM stage & N/A & $\mathrm{N} / \mathrm{A}$ & N/A & N/A & N/A & N/A \\
\hline Lymph node metastasis & N/A & N/A & N/A & N/A & N/A & N/A \\
\hline LAPTM4B & 1.730 & $1.163-2.574$ & $0.007 *$ & 1.839 & $1.239-2.730$ & $0.002 *$ \\
\hline VEGF & N/A & N/A & N/A & N/A & N/A & N/A \\
\hline Nuclear survivin & N/A & $\mathrm{N} / \mathrm{A}$ & $\mathrm{N} / \mathrm{A}$ & $\mathrm{N} / \mathrm{A}$ & $\mathrm{N} / \mathrm{A}$ & $\mathrm{N} / \mathrm{A}$ \\
\hline Cytoplasmic survivin & N/A & N/A & N/A & N/A & N/A & N/A \\
\hline
\end{tabular}

OS, overall survival; PFS, progression-free survival; RR, relative risk; CI, confidence interval.

${ }^{a}$ Cox regression test.

$* \mathrm{P}<0.05$.

they could have clinical potential as promising prognostic markers to identify individuals with poor outcomes and may be regarded as therapeutic targets for breast cancer. However, the limitations in this study included the small sample size and its retrospective nature, such as the limited follow-up time, which could be why the expression of VEGF and survivin was not linked to OS and PFS in the multivariate analysis.

\section{MATERIALS AND METHODS}

\section{Patients and tissue samples}

Specimens were collected from 110 breast cancer patients with stages I-III and 10 patients with benign breast tumors who underwent surgical resection at the Beijing Cancer Hospital between January 2011 and July 2013. All patients provided written informed consent, and none of the patients received chemotherapy, immunotherapy, or radiotherapy before surgery. The Ethics Committee of Beijing Cancer Hospital approved this protocol. All patients with breast cancer were followed-up for the survival analysis until September 2016 (median, 49 months; range, 10-67 months).

\section{Immunohistochemical staining}

Paraffin-embedded samples were cut into fourmicrometer sections and stained with hematoxylin and eosin for tumor confirmation. Selected sections were immersed in a retrieval buffer solution for antigen recovery and incubated with a polyclonal rabbit antiLAPTM4B antibody (dilution 1:200, bs-6542R, Bioss, USA), a polyclonal rabbit anti-VEGF antibody (dilution 1:150, ZA-0509, ZSGB, China) and a monoclonal mouse anti-survivin antibody (dilution 1:2000, produced by our lab) overnight at $4^{\circ} \mathrm{C}$. Finally, the slides were stained and mounted. Negative controls were provided by replacing the primary antibodies with normal goat serum.

\section{Staining evaluation}

LAPTM4B, VEGF, and survivin protein expression levels were semi-quantitatively classified. The percentage of positive cells was measured as follows: 0 , less than $9 \%$ staining; $1,10 \%$ to $25 \%$ staining; $2,26 \%-50 \%$ staining; $3,51 \%-75 \%$ staining and $4,>75 \%$ staining. The staining intensity was evaluated as follows: 0 , no staining; 1 , weak staining; 2 , moderate staining; 3 , strong staining. The total score of stained cells was calculated by multiplying the above two scores to define the expression levels: 0 , negative expression; 1 to 4 , weak expression; 5 to 8 , positive expression; 9 to 12 , strong expression. Tumor tissues with scores of $0-4$ were defined as having low expression and those with scores of $5-12$, as having high expression.

\section{Follow-up}

Each patient was scheduled for an examination, which included a physical examination, blood analysis, and computed tomography analysis. Tumor progression was based on clinical, radiological or histological diagnosis, and the site and time of tumor progression were both recorded. Follow-up was performed until September 2016 for 110 patients.

\section{Cell lines}

Breast cancer cell lines (MDA-MB-231, ZR75-1, T47D, and MCF-7) were kindly provided by Dr. SHOU Cheng-chao from Department of Biochemistry and Molecular Biology, Peking University Cancer 
Hospital \& Institute. MCF-10A cells were obtained from MeiXuan Biological Technology Company Limited of Shanghai, China. They were cultured in appropriate media supplemented with essential materials in the $5 \% \mathrm{CO}_{2}$ incubator [31].

\section{Western blot analysis}

Protein extracts were separated via $12 \%$ SDS polyacrylamide gel electrophoresis and transferred onto PVDF filters. The filters were incubated with a rabbit anti-LAPTM4B polyclonal antibody (dilution 1:1000, AP20870a, ABGENT, China), a rabbit antiVEGF polyclonal antibody (dilution 1:500, 19003-1-AP, Proteintech, USA) and a rabbit anti-survivin monoclonal antibody (dilution 1:1000, 2808, Cell Signaling Technology, USA) overnight at $4^{\circ} \mathrm{C}$. The blots were detected using a chemiluminescence detection system. $\beta$-Actin and histone $\mathrm{H} 3$ were used as internal controls for the total, cytoplasmic protein expression and nuclear protein expression.

\section{Statistical analysis}

SPSS 18.0 software was used to perform the statistical analyses, and $\chi 2$ tests were used to evaluate the associations between the three biomarkers and the clinicopathological characteristics. The follow-up data was analyzed using the Kaplan-Meier method and Cox regression tests. $\mathrm{P}<0.05$ was considered statistically significant.

\section{Author contributions}

Sha Li carried out experiments, analyzed results and drafted the manuscript. Lu Wang, Yue Meng, Yanli Chang and Jianjun $\mathrm{Xu}$ performed partial experiments and analyzed some data. Qingyun Zhang designed the study, interpreted the data and revised the manuscript for important intellectual content.

\section{ACKNOWLEDGMENTS}

We would like to thank all people who participated in the study.

\section{CONFLICTS OF INTEREST}

The authors have declared that no competing interests exist.

\section{FUNDING}

This work was supported by the National Natural Science Foundation of China (No. 81572910).

\section{REFERENCES}

1. Ferlay J, Soerjomataram I, Dikshit R, Eser S, Mathers C, Rebelo M, Parkin DM, Forman D, Bray F. Cancer incidence and mortality worldwide: sources, methods and major patterns in GLOBOCAN 2012. Int J Cancer. 2015; 136: E359-E386.

2. Liu XR, Zhou RL, Zhang QY, Zhang Y, Jin YY, Lin M, Rui JA, Ye DX. Structure analysis and expressions of a novel tetratransmembrane protein, lysosoma-associated protein transmembrane 4 beta associated with hepatocellular carcinoma. World J Gastroenterol. 2004; 10: 1555-1559.

3. Shao GZ, Zhou RL, Zhang QY, Zhang Y, Liu JJ, Rui JA, Wei X, Ye DX. Molecular cloning and characterization of LAPTM4B, a novel gene upregulated in hepatocellular carcinoma. Oncogene. 2003; 22: 5060-5069.

4. Zhang H, Tian B, Yu H, Yao H, Gao Z. LAPTM4B-35 protein as a potential therapeutic target in gastric cancer. Tumour Biol. 2014; 35: 12737-12742.

5. Zhou L, He XD, Yu JC, Zhou RL, Shan Y, Rui JA. Overexpression of LAPTM4B-35 attenuates epirubucininduced apoptosis of gallbladder carcinoma GBC-SD cells. Surgery. 2011; 150: 25-31.

6. Maki Y, Fujimoto J, Lang W, Xu L, Behrens C, Wistuba, II, Kadara H. LAPTM4B is associated with poor prognosis in NSCLC and promotes the NRF2-mediated stress response pathway in lung cancer cells. Sci Rep. 2015; 5: 13846.

7. Meng Y, Wang L, Chen D, Chang Y, Zhang M, Xu JJ, Zhou $\mathrm{R}$, Zhang QY. LAPTM4B: an oncogene in various solid tumors and its functions. Oncogene. 2016; 35: 6359-6365.

8. Arcondéguy T, Lacazette E, Millevoi S, Prats H, Touriol C. VEGF-A mRNA processing, stability and translation: a paradigm for intricate regulation of gene expression at the post-transcriptional level. Nucleic Acids Res. 2013; 41: 7997-8010.

9. Tang N, Shi L, Yu Z, Dong P, Wang C, Huo X, Zhang B, Huang S, Deng S, Liu K, Ma T, Wang X, Wu L, et al. Gamabufotalin, a major derivative of bufadienolide, inhibits VEGF-induced angiogenesis by suppressing VEGFR-2 signaling pathway. Oncotarget. 2016; 7: 3533-3547. doi: 10.18632/oncotarget.6514.

10. Choi JW, Kim HA, Nam K, Na Y, Yun CO, Kim S. Hepatoma targeting peptide conjugated bio-reducible polymer complexed with oncolytic adenovirus for cancer gene therapy. J Control Release. 2015; 220: 691-703.

11. Vumbaca F, Phoenix KN, Rodriguez-Pinto D, Han DK, Claffey KP. Double-stranded RNA-binding protein regulates vascular endothelial growth factor mRNA stability, translation, and breast cancer angiogenesis. Mol Cell Biol. 2008; 28: 772-783.

12. Pennati M, Folini M, Zaffaroni N. Targeting survivin in cancer therapy: fulfilled promises and open questions. Carcinogenesis. 2007; 28: 1133-1139.

13. Bisle S, Klingenbeck L, Borges V, Sobotta K, SchulzeLuehrmann J, Menge C, Heydel C, Gomes JP, Lührmann 
A. The inhibition of the apoptosis pathway by the Coxiella burnetii effector protein CaeA requires the EK repetition motif, but is independent of survivin. Virulence. 2016; 7: 400-412.

14. Tanaka K, Iwamoto S, Gon G, Nohara T, Iwamoto M, Tanigawa N. Expression of survivin and its relationship to loss of apoptosis in breast carcinomas. Clin Cancer Res. 2000; 6: 127-134.

15. Kim JS, Kim HA, Seong MK, Seol H, Oh JS, Kim EK, Chang JW, Hwang SG, Noh WC. STAT3-survivin signaling mediates a poor response to radiotherapy in HER2-positive breast cancers. Oncotarget. 2016; 7: 7055-7065. doi: 10.18632/oncotarget.6855.

16. Li L, Shan Y, Yang H, Zhang S, Lin M, Zhu P, Chen XY, Yi J, McNutt MA, Shao GZ, Zhou RL. Upregulation of LAPTM4B-35 promotes malignant transformation and tumorigenesis in L02 human liver cell line. Anat Rec (Hoboken). 2011; 294: 1135-1142.

17. Meng F, Chen X, Song H, Lou G. LAPTM4B down regulation inhibits the proliferation, invasion and angiogenesis of HeLa cells in vitro. Cell Physiol Biochem. 2015; 37: 890-900.

18. Meng F, Tan S, Liu T, Song H, Lou G. Predictive significance of combined LAPTM4B and VEGF expression in patients with cervical cancer. Tumour Biol. 2016; 37: 4849-4855.

19. Visvanathan K, Fackler MS, Zhang Z, Lopez-Bujanda ZA, Jeter SC, Sokoll LJ, Garrett-Mayer E, Cope LM, Umbricht CB, Euhus DM, Forero A, Storniolo AM, Nanda $\mathrm{R}$, et al. Monitoring of serum DNA methylation as an early independent marker of response and survival in metastatic breast cancer: TBCRC 005 prospective biomarker study. J Clin Oncol. 2017; 35:751-758. doi: 10.1200/ JCO.2015.66.2080.

20. Li M, Zhou R, Shan Y, Li L, Wang L, Liu G. Targeting a novel cancer-driving protein (LAPTM4B-35) by a small molecule (ETS) to inhibit cancer growth and metastasis. Oncotarget. 2016; 7: 58531-58542. doi: 10.18632/oncotarget.11325.

21. Xiao M, Jia S, Wang $H$, Wang J, Huang Y, Li Z. Overexpression of LAPTM4B: an independent prognostic marker in breast cancer. J Cancer Res Clin Oncol. 2013; 139: 661-667.

22. Fernández JG, Rodríguez DA, Valenzuela M, Calderon C, Urzúa U, Munroe D, Rosas C, Lemus D, Díaz N, Wright
MC, Leyton L, Tapia JC, Quest AF. Survivin expression promotes VEGF-induced tumor angiogenesis via PI3K/Akt enhanced $\beta$-catenin/Tcf-Lef dependent transcription. Mol Cancer. 2014; 13: 209.

23. Ryan BM, Konecny GE, Kahlert S, Wang HJ, Untch M, Meng G, Pegram MD, Podratz KC, Crown J, Slamon DJ, Duffy MJ. Survivin expression in breast cancer predicts clinical outcome and is associated with HER2, VEGF, urokinase plasminogen activator and PAI-1. Ann Oncol. 2006; 17: 597-604.

24. Tang H, Tian H, Yue W, Li L, Li S, Gao C, Si L, Qi L, Lu M. Overexpression of LAPTM4B is correlated with tumor angiogenesis and poor prognosis in non-small cell lung cancer. Med Oncol. 2014; 31: 974.

25. Li FZ, Yang J, Ramnath N, Javle MM, Tan DF. Nuclear or cytoplasmic expression of survivin: what is the significance? Int J Cancer. 2005; 114: 509-512.

26. Rexhepaj E, Jirstrom K, O'Connor DP, O'Brien SL, Landberg G, Duffy MJ, Brennan DJ, Gallagher WM. Validation of cytoplasmic-to-nuclear ratio of survivin as an indicator of improved prognosis in breast cancer. BMC Cancer. 2010; 10: 639.

27. Kleinberg L, Flørenes VA, Silins I, Haug K, Trope CG, Nesland JM, Davidson B. Nuclear expression of survivin is associated with improved survival in metastatic ovarian carcinoma. Cancer. 2007; 109: 228-238.

28. Beghein E, van Audenhove I, Zwaenepoel O, Verhelle A, de Ganck A, Gettemans J. A new survivin tracer tracks, delocalizes and captures endogenous survivin at different subcellular locations and in distinct organelles. Sci Rep. 2016; 6: 31177.

29. Fan M, Liu Y, Zhou R, Zhang Q. Association of LAPTM4B gene polymorphism with breast cancer susceptibility. Cancer Epidemiol. 2012; 36: 364-368.

30. Li X, Kong X, Chen X, Zhang N, Jiang L, Ma T, Yang Q. LAPTM4B allele *2 is associated with breast cancer susceptibility and prognosis. PLoS One. 2012; 7: e44916.

31. Wang-Johanning F, Rycaj K, Plummer JB, Li M, Yin B, Frerich K, Garza JG, Shen J, Lin K, Yan P, Glynn SA, Dorsey TH, Hunt KK, et al. Immunotherapeutic potential of anti-human endogenous retrovirus-K envelope protein antibodies in targeting breast tumors. J Natl Cancer Inst. 2012; 104: 189-210. 